\title{
Project planning and project implementation success in Rwanda: A case of Sebeya Watershed Management Project, Rubavu District
}

\author{
Mathias KARASIRA ${ }^{1}$, Dr. Eugenia Nkechi Irechukwu ${ }^{2}$ \\ ${ }^{1}$ School of Business and Economics, Mount Kenya University, Kigali, Rwanda \\ ${ }^{2}$ School of Business and Economics, Mount Kenya University, Kigali, Rwanda \\ DOI: 10.29322/IJSRP.11.12.2021.p12022 \\ http://dx.doi.org/10.29322/IJSRP.11.12.2021.p12022
}

\begin{abstract}
The purpose of this study was to analyze the effect of project planning on the project implementation success in Rwanda using a case of Sebeya Water Resource Board in Rubavu District. The specific objectives of the study were to identify the effect of scope planning in project implementation, to analyze resource planning in project implementation and to assess the effect of duty planning in project implementation at Sebeya watershed management project by Rwanda water resource Board, Rubavu District. The study is helpful in acquiring skills on how watershed management project is planned and skills that beneficiaries have

$\mathrm{D}$
\end{abstract} in executing this project which stimulates its effective implementation. Future studies related will use results from this study to obtain a useful literature review. A descriptive research design with a correlation coefficient r-size effect was used. This research used both qualitative and quantitative approaches. The target population comprises of 1170 employees working in the project and 9 key informants, a sample size of 138 respondents calculated using Slovene's formula was selected using purposive and simple random sampling techniques. Due to COVID-19 prevention measures, online data collection tool and phone interviews were used where possible to local leaders and questionnaire were distributed by youth volunteers. A questionnaire was administered to respondents, interview guide was held with key informants. Quantitative data was analyzed using statistical package for social sciences version 26.0 and qualitative data was analyzed using content analysis based on research objectives. The study found a positive correlation between scope planning and efficiency $(\mathrm{r}=.890, \mathrm{p}=0.000)$, scope planning and productivity $\left(\mathrm{r}=.935^{* *}, \mathrm{p}=0.000\right.$, scope planning and control $(\mathrm{r}=.893 * *=0.000)$. Results demonstrated that a positive correlation between resource planning and efficiency $(\mathrm{r}=.891, \mathrm{p}=0.039)$, resource planning and productivity $(\mathrm{r}=.896, \mathrm{p}=0.000)$ resource planning and control $(\mathrm{r}=.853, \mathrm{p}=0.000)$. Furthermore, it was evidenced, a positive correlation between duty planning and efficiency $(\mathrm{r}=.953, \mathrm{p}=0.000)$, duty planning and productivity $(\mathrm{r}=.890, \mathrm{p}=0.000)$, duty planning and control $(\mathrm{r}=.875, \mathrm{p}=.0 .000)$. All the above, relationship is positively correlated given that the $p$ value was $<0.005$ proposing than an enhanced in project planning led to the success of project implementation for Sebeya Watershed Management in Rwanda. The study recommends that all project should focus on planning for assessing their short, medium and long-term effect implementation success; this is therefore, owing to planning is helpful in understanding the condition in which they are working and how to address about it.

Index Terms- Project, Project Planning, Duty Planning, Resource Planning, Scope Planning, Project Success.

\section{INTRODUCTION} espite, a significant role of project planning on project success in Rwanda, most of project are failing such as intensive labor program (Ntanyoma, 2010), adult literacy program, (Rwanda Agriculture Board,2013), lateral terraces in Gatsibo District (Ruberangeyo, et al.,2011) and tailoring project for young girls in Musanze Distrcit (Mutarutwa, 2014). Previous studies evidenced that project failure is characterized by inefficiency, poor productivity and lack of effective control (NIS, 2011). There is also high degradation, lack of access to water, erosion in watershed management activities (Kayigema \& Rugege, 2014).

The greatest impediment to project success is lack of proper project planning from the initiation to the implementation. In fact, the lack of adequate, scope planning, resource planning and duty planning are deemed to be contributing factors that lead to the failure of project (Harris, 2010).

In search of ways to overcome project failure, it was contended that effective project planning processes may lead to project implementation success. There are different project planning processes for ensuring the project success. Some of these processes would not be adequate and effective for particular project (Yang et al., 2011). Most of studies pointed out the pertinence of scope planning (Adera, 2013), resource planning (Novo et al., 2017), duty planning (Naqvi \& Aziz, 2011). In light with the above empirical evidences, this research sought to examine the contribution of project planning on project implementation success in Rwanda using a case of watershed management project in Rubavu District, Rwanda to come up with roots causes of these issues and establish strategies to reduce the problems.

The research objectives were:

(i)To identify the effect of scope planning in project implementation at Sebeya watershed management project by Rwanda water resource Board, Rubavu District 
(ii)To analyze resource planning in project implementation at Sebeya watershed management project by Rwanda water resource Board, Rubavu District

(iii)To assess the effect of duty planning in project implementation at Sebeya watershed management project by Rwanda water resource Board, Rubavu District.

\section{REVIEW OF LITERATURE}

According Yana, (2018), project scope planning is associated to carrying out processes that identify, plan, control the implementation of the required amount of project work. In fact, scope planning is an explanation of the required amount of project work to ensure successful accomplishment of the planned project. On the one hand, an inadequate amount of work can lead to the complexity of treatment them, loss of organization efficiency. Other meaning, may detail can require a lot of money and time to plan each work and to monitor its implementation. Therefore, the project scope management determines the number and scope of project work that is necessary and sufficient for the effective implementation of the project work.

In project implementation, the term "scope" takes into account three components: product content, the content of works, project content. According to the project organization guide Body of Knowledge, the term "scope" refers to the content of the product or the satisfied of the entire project, (Yana, 2018). The scope of the project is considered to be the content of the work, for the effective supervision of which it is necessary to define: the activities to be carried out; order of work; Work period; funds needs and cost of work. The project scope management takes into account the definition of content, the design of the project work, the definition of the composition of works, satisfied control. The reason of the description of the project scope is to recognize the essence of the project scope, its objectives, results, requirements, and limits by analyzing the closing state of the project. Determining the content of the project shows the support of the project to the implementation of planned objectives of the project. A detailed explanation of the project scope is the foundation of all project decisions, a base that links the prominence of the project and the outputs that should be increased as a result of an effective project implementation, (Moroz, 2017).

A study conducted by Yang et al. (2011) on integrated planning and sustainable investment programs in China, intended to know integral flow, plan for project investment on the success of project. The research adopted a critical analysis and felt that positive and negative effects of project planning practices, introducing new viewpoints for advancing more increased approaches and systems. Novo et, al. (2017) assessed the effect of project management on project success in China with the aim to investigate the contribution of management. This study utilized desk review and revealed that design management is hardly contained in project planning processes, it stimulates its success via different patterns, such as team work knowledge, managers skills and methods with both stakeholder and beneficiaries.

Study research carried out by Fatima et al (2013) on the role of change management on project implementation success in Malasia used desk review and indicated that most of project failed owing to poor management. The study recommended suitable management for adequate execution of project by relying on project planning practices. Another study on project management practices was carried out to assess its contribution to the success of industries in Ghana. The study determined the level of quality of planning practices. The research used an exploratory research design and questionnaire survey to gather information on project management in Ghana using a sample size of 200 stakeholders from diverse economic industries (Ofori, 2013). Findings revealed that critical parameters that play a role to the performance of projects are top management suppose, risk management plan, clarification of objectives.

Naqvi, et, al. (2011) assessed the role of stakeholder communication on project performance. The study aimed at assessing the effects of training, monitoring and evaluation, leadership and management parameters on project sustainability. The study was conducted descriptively using 13 groups of young population. Information was discussed using descriptive statistical method. Findings were presented in tables and percentages by revealing that effective budget plan, financial management, adequate instruments affect youth project sustainability in Kenya.

According Obadia and Patrick, (2018), an effective project implementation comprises institute of the corporation's funds and inspiration of the staff to achieve goals. Effective site activities are about working in group and follow a common goal, membership and be informed with each other in their daily activities about what they have to do for successfully performing their duties. The price of plan and its proficient contributions contain growing output, reducing inputs, increasing returns, and improving service for getting the quality products. They distinguished that it may be very simple to think of an effective plan than it is to implement it as much of the inadequacies in management area is attributable to failures in the implementation process rather than in the making of plan oneself. Every action is distributed with a particular funds and must be accomplished within the limited period, then it may undesirably affect the whole plan of the project. Hence, the best arrangement of resources to use for performing a project-activities is required to manage the effective accomplishment of the project, (Irugal, 2020).

Finally, a duty planning is a significant factor that definitely enhances a success of project implementation, by Heldman (2011), the project duties' planning knowledge area is related with setting the responsibilities capacity to every employee during the project plan activities, putting the employees in positions according project agenda, and monitoring and evaluation their performances from the plan. Duty planning is an essential aspect of project organization as it preserves the project activities on pathway those activities in contradiction of the project plan to make sure the project is accomplished on suggested period with enough results and control that project objectives are completely done with a success of project.

According to Madanipour, (2015), the developments that establish project duty planning comprise the following techniques such as activity definition, activity arrangement, employee capacity, activity period estimating, schedule advancement and project program control. Duty planning and organization is a significant aspect of project implementation because it concerns saving the project activities on pathway, direction and observing 
those actions against the project design through structure of organization in order ensure that the employees are performing well and project will achieve on the objective on right time, Heldman, (2011).

\section{Independent Variable}

\section{Project Planning}

\section{Scope Planning}

- Defining course of activities

- Sequencing activities

- Estimation time of activities

- Scheduling development

Resource Planning

- Cost estimation

- Cost budgeting

- Provision of the basis for budget control

- Resource planning

\section{Duty Planning}

- Capacity of Employees

- Flexibility of Employees

- Collaboration of Employees

- Arrangement of activities
The below diagram indicates that there is a relationship between the term conceptual framework denotes a diagram showing the relationship between research variables.

\section{Dependent Variable}

\section{Project Implementation Success \\ - Efficiency \\ - Productivity \\ - Control}

\section{Figure 2. 1 Conceptual Framework}

Information presented in Figure 2.1 gives the link among research variables. In this study, project planning is independent variable, watershed management project success is dependent variable while intervening variables are government policies and beneficiaries' involvement. Therefore, independent variable was analyzed through scope planning, resource planning and duty planning. The ultimate objective of plan is to attain short- and long-term targets within an expected time, planned budgetary costs and parameters of success. Finally, it is very pertinent to know that the level of project success relies on considering potential risks and elucidate copying strategies to overcome them. Both independent and dependent variables were moderated by intervening variables which are government policies and beneficiaries Involvement.

Here the figure shows that intervening variable impact on independent variable and affects either positively or negatively the dependent variable. Those intervening variables are, government policies, beneficiaries Involvement, local authorities, NGOs, ministry of agriculture, ministry of finance. The dependent variable which is project success was affected according to the contribution of intervening variables and that stimulate the realization of efficiency, productivity and control. 


\section{MATERIALS AND METHODS}

According to Creswell (2013), a research design denotes a blueprint or plan applied in carrying out any research. The study strategy and paradigm that guide any research. In fact, this study used a descriptive research design and regression with correlation r-size effect to establish the effect of project planning variables on project success variables, where a mixed approach was used. Owing to the issue of COVID-19, the research used online questionnaire survey and telephone interviews to access key informants and project employees. Research instruments were translated into Kinyarwanda and were distributed to youth volunteers who assisted the researcher in collecting information.

The study population comprised of 1170 employees of Sebeya catchment management project implemented by Rwanda water resource board of Rubavu District in all categories of employees and four project staff members, in Rubavu District (Rubavu, 2020).

The sample size was calculated using Slovene's formula. Therefore, sample size is calculated by the Slovene's formula:

$\boldsymbol{n}=\frac{N}{1+N(e)^{2}}$

In this regards, $\mathrm{n}=$ sample size, $\mathrm{N}=$ population size, $\mathrm{e}=$ margin error $(0.05)$, and 1 is the constant. $0.05 \%$ was utilized as the sampling the level of precision. This number of $5 \%$ is taken for making the correction of voluntary and/ or involuntary errors done by the respondents. Therefore: $n=1170 / 1+1170(0.05) ; n$ $=1170 / 1+1170(0.0025) ; \mathrm{n}=1170 / 1+2.925 ; \mathrm{n}=1170 / 3.925=$ $298.0891719745223=299$.

The formula resulted that from 1170 population, the calculated sample size is equal 299 employees of Sebeya watershed management project of RWB at Rubavu District. The study used primary and secondary data sources. Primary data source was gathered through the use of questionnaire survey that was distributed to employees ibn the watershed management project at Sebeya-Rubavu District. Quantitative information was analyzed through descriptive statistics and regression with correlation r-size effect to show effect of project planning on project success.

\section{RESULTS AND DISCUSSION}

\subsubsection{Effect of Scope Planning on Implementation of Sebeya} Watershed Management Project

The project scope planning was assessed using definition of course of activities, sequence of activities, estimation time of activities and schedule development. 


\section{Correlation between Project Scope Planning and Sebeya Watershed Management Success}

\begin{tabular}{|c|c|c|c|c|c|c|c|c|}
\hline & & $\begin{array}{l}\text { Course of } \\
\text { activities } \\
\text { has been } \\
\text { defined } \\
\text { clearly }\end{array}$ & $\begin{array}{l}\text { Activities } \\
\text { were } \\
\text { adequately } \\
\text { sequenced }\end{array}$ & $\begin{array}{l}\text { Time of } \\
\text { activities } \\
\text { was early } \\
\text { estimated }\end{array}$ & $\begin{array}{l}\text { Schedule } \\
\text { development } \\
\text { has been done }\end{array}$ & $\begin{array}{l}\text { Improved } \\
\text { efficiency }\end{array}$ & $\begin{array}{l}\text { Increased } \\
\text { productivity }\end{array}$ & $\begin{array}{l}\text { Increased } \\
\text { control }\end{array}$ \\
\hline \multicolumn{2}{|c|}{$\begin{array}{l}\text { Course of activities Pearson } \\
\text { has been defined Correlation }\end{array}$} & 1 & $.944^{* *}$ & $.934^{* *}$ & $.915^{* *}$ & $.915^{* *}$ & $.871^{* *}$ & $.840^{* *}$ \\
\hline \multirow[t]{2}{*}{ clearly } & Sig. (2-tailed) & & .000 & .000 & .000 & .000 & .000 & .000 \\
\hline & $\mathrm{N}$ & 276 & 276 & 276 & 276 & 276 & 276 & 276 \\
\hline \multirow{3}{*}{$\begin{array}{l}\text { Activities } \\
\text { adequately } \\
\text { sequenced }\end{array}$} & $\begin{array}{l}\text { Pearson } \\
\text { Correlation }\end{array}$ & $.944^{* *}$ & 1 & $.941^{* *}$ & $.890^{* *}$ & $.929^{* *}$ & $.840^{* *}$ & $.838^{* *}$ \\
\hline & Sig. (2-tailed) & .000 & & .000 & .000 & .000 & .000 & .000 \\
\hline & $\mathrm{N}$ & 276 & 276 & 276 & 276 & 276 & 276 & 276 \\
\hline \multirow[t]{3}{*}{$\begin{array}{l}\text { Time of activities } \\
\text { was early estimated }\end{array}$} & $\begin{array}{l}\text { s Pearson } \\
\text { Correlation }\end{array}$ & $.934^{* *}$ & $.941^{* *}$ & 1 & $.933^{* *}$ & $.908^{* *}$ & $.886^{* *}$ & $.848^{* *}$ \\
\hline & Sig. (2-tailed) & .000 & .000 & & .000 & .000 & .000 & .000 \\
\hline & $\mathrm{N}$ & 276 & 276 & 276 & 276 & 276 & 276 & 276 \\
\hline \multirow{3}{*}{$\begin{array}{l}\text { Schedule } \\
\text { development } \\
\text { been done }\end{array}$} & $\begin{array}{l}\text { Pearson } \\
\text { s Correlation }\end{array}$ & $.915^{* *}$ & $.890^{* *}$ & $.933^{* *}$ & 1 & $.849^{* *}$ & $.932^{* *}$ & $.887^{* *}$ \\
\hline & Sig. (2-tailed) & .000 & .000 & .000 & & .000 & .000 & .000 \\
\hline & $\mathrm{N}$ & 276 & 276 & 276 & 276 & 276 & 276 & 276 \\
\hline \multirow[t]{3}{*}{ Improved efficiency } & $\begin{array}{l}\text { Pearson } \\
\text { Correlation }\end{array}$ & $.915^{* *}$ & $.929^{* *}$ & $.908^{* *}$ & $.849^{* *}$ & 1 & $.844^{* *}$ & $.851^{* *}$ \\
\hline & Sig. (2-tailed) & .000 & .000 & .000 & .000 & & .000 & .000 \\
\hline & $\mathrm{N}$ & 276 & 276 & 276 & 276 & 276 & 276 & 276 \\
\hline \multirow[t]{3}{*}{$\begin{array}{l}\text { Increased } \\
\text { productivity }\end{array}$} & $\begin{array}{l}\text { Pearson } \\
\text { Correlation }\end{array}$ & $.871^{* *}$ & $.840^{* *}$ & $.886^{* *}$ & $.932^{* *}$ & $.844^{* *}$ & 1 & $.928^{* *}$ \\
\hline & Sig. (2-tailed) & .000 & .000 & .000 & .000 & .000 & & .000 \\
\hline & $\mathrm{N}$ & 276 & 276 & 276 & 276 & 276 & 276 & 276 \\
\hline \multirow[t]{3}{*}{ Increased control } & $\begin{array}{l}\text { Pearson } \\
\text { Correlation }\end{array}$ & $.840^{* * *}$ & $.838^{* *}$ & $.848^{* *}$ & $.887^{* *}$ & $.851^{* *}$ & $.928^{* *}$ & 1 \\
\hline & Sig. (2-tailed) & .000 & .000 & .000 & .000 & .000 & .000 & \\
\hline & $\mathrm{N}$ & 276 & 276 & 276 & 276 & 276 & 276 & 276 \\
\hline
\end{tabular}

**. Correlation is significant at the 0.01 level (2-

tailed).

\section{Source: Primary Data}

The study findings reveal correlation between variables. For defining course of activities, there is a positive insignificant correlation between defining course of activities and productivity $(\mathrm{r}=0.915, \mathrm{p}=0.000)$ and defining course of activities with productivity $(\mathrm{r}=0.871, \mathrm{p}=0.000)$ and defining course of activities and control( $(\mathrm{r}=0.840), \mathrm{p}$ value $=0.000)$. These correlations are statistically significant given that the $\mathrm{p}$ value was $<0.05$ implying that the rise of defining course of activities affect efficiency, productivity and control and vice versa.

For sequencing activities, there are positive and significant correlation between sequencing activities and efficiency $(\mathrm{r}=0.929$, $\mathrm{p}=0.000)$, sequencing activities and productivity $(0.840, \mathrm{p}$ value $=0.000)$ and with control $(\mathrm{r}=0.838, \mathrm{p}=0.000)$ statistically correlated given the $\mathrm{p}$ value is $<0.005$ proposing that increase in sequencing activities leads to increase in efficiency, productivity and control and vice versa.

Results on the correlation between time of activities was early estimated and dependent variables, there is significant correlation time of activities was early estimated and efficacy $(\mathrm{r}=0.849, \mathrm{p}$ value $=0.000)$, time of activities was early estimated and productivity $(\mathrm{r}=0.932, \mathrm{p}=0.000)$, time of activities was early estimated and control $(\mathrm{r}=0.848, \mathrm{p}=0.000) \mathrm{v}$. These are statistically significant given that the $\mathrm{p}$ value was $<0.05$ implying that the rise of estimation time of activities project implementation success.

Results on the correlation between schedule development has been done and dependent variables, there is significant correlation schedule development has been done and efficacy $(\mathrm{r}=0.908, \mathrm{p}$ value $=0.000)$, schedule development has been done 
and productivity $(\mathrm{r}=0.886, \mathrm{p}=0.000)$, schedule development has been done and control $(\mathrm{r}=0.887, \mathrm{p}=0.000) \mathrm{v}$. These are statistically significant given that the $\mathrm{p}$ value was $<0.05$ implying that the rise of Schedule development has been done affect the success of Sebeya watershed management.

\subsection{Effect of Project Resource Planning on Implementation Success of Sebeya Watershed Management Project}

The project effect of project resource planning on implementation success of Sebeya watershed management project was undertaken Sebeya-Rubavu Distrcit.

\section{Correlation Analysis between Resource Planning and Implementation Success of Sebeya Watershed Management Project}

\begin{tabular}{|c|c|c|c|c|c|c|c|c|}
\hline & & $\begin{array}{l}\text { Cost } \\
\text { estimation }\end{array}$ & $\begin{array}{l}\text { Cost } \\
\text { budgeting }\end{array}$ & $\begin{array}{l}\text { Provisio } \\
\text { the basi } \\
\text { budget } \\
\text { control }\end{array}$ & $\begin{array}{l}\text { needed } \\
\text { material } \\
\text { planning }\end{array}$ & $\begin{array}{l}\text { Improved } \\
\text { efficiency }\end{array}$ & $\begin{array}{l}\text { Increased } \\
\text { productivity }\end{array}$ & $\begin{array}{l}\text { Increased } \\
\text { control }\end{array}$ \\
\hline \multirow[t]{3}{*}{ Cost estimation } & $\begin{array}{l}\text { Pearson } \\
\text { Correlation }\end{array}$ & 1 & $.981^{* * *}$ & $.977^{* *}$ & $.947^{* *}$ & $.885^{* *}$ & $.934^{* *}$ & $.897^{* *}$ \\
\hline & Sig. (2-tailed) & & .000 & .000 & .000 & .000 & .000 & .000 \\
\hline & $\mathrm{N}$ & 276 & 276 & 276 & 276 & 276 & 276 & 276 \\
\hline \multirow[t]{3}{*}{ Cost budgeting } & $\begin{array}{l}\text { Pearson } \\
\text { Correlation }\end{array}$ & $.981^{\text {*** }}$ & 1 & $.978^{* *}$ & $.946^{* * *}$ & $.881^{* * *}$ & $.964^{* *}$ & $.913^{* *}$ \\
\hline & Sig. (2-tailed) & .000 & & .000 & .000 & .000 & .000 & .000 \\
\hline & $\mathrm{N}$ & 276 & 276 & 276 & 276 & 276 & 276 & 276 \\
\hline \multirow[t]{3}{*}{$\begin{array}{l}\text { Provision of the basis } \\
\text { for budget control }\end{array}$} & $\begin{array}{l}\text { Pearson } \\
\text { Correlation }\end{array}$ & $.977^{* *}$ & $.978^{* *}$ & 1 & $.966^{* *}$ & $.890^{* *}$ & $.935^{* *}$ & $.893^{* *}$ \\
\hline & Sig. (2-tailed) & .000 & .000 & & .000 & .000 & .000 & .000 \\
\hline & $\mathrm{N}$ & 276 & 276 & 276 & 276 & 276 & 276 & 276 \\
\hline \multirow[t]{3}{*}{$\begin{array}{l}\text { needed } \\
\text { planning }\end{array}$} & $\begin{array}{l}\text { Pearson } \\
\text { Correlation }\end{array}$ & $.947^{* *}$ & $.946^{* *}$ & $.966^{* *}$ & 1 & $.891^{* *}$ & $.896^{* *}$ & $.853^{* *}$ \\
\hline & Sig. (2-tailed) & .000 & .000 & .000 & & .000 & .000 & .000 \\
\hline & $\mathrm{N}$ & 276 & 276 & 276 & 276 & 276 & 276 & 276 \\
\hline \multirow[t]{3}{*}{ Improved efficiency } & $\begin{array}{l}\text { Pearson } \\
\text { Correlation }\end{array}$ & $.885^{* *}$ & $.881^{* * *}$ & $.890^{* *}$ & $.891^{* *}$ & 1 & $.844^{* *}$ & $.851^{* *}$ \\
\hline & Sig. (2-tailed) & .000 & .000 & .000 & .000 & & .000 & .000 \\
\hline & $\mathrm{N}$ & 276 & 276 & 276 & 276 & 276 & 276 & 276 \\
\hline \multirow[t]{3}{*}{$\begin{array}{l}\text { Increased } \\
\text { productivity }\end{array}$} & $\begin{array}{l}\text { Pearson } \\
\text { Correlation }\end{array}$ & $.934^{* *}$ & $.964^{* *}$ & $.935^{* *}$ & $.896^{* *}$ & $.844^{* *}$ & 1 & $.928^{* *}$ \\
\hline & Sig. (2-tailed) & .000 & .000 & .000 & .000 & .000 & & .000 \\
\hline & $\mathrm{N}$ & 276 & 276 & 276 & 276 & 276 & 276 & 276 \\
\hline \multirow[t]{3}{*}{ Increased control } & $\begin{array}{l}\text { Pearson } \\
\text { Correlation }\end{array}$ & $.897^{* *}$ & $.913^{* *}$ & $.893^{* *}$ & $.853^{* *}$ & $.851^{* *}$ & $.928^{* *}$ & 1 \\
\hline & Sig. (2-tailed) & .000 & .000 & .000 & .000 & .000 & .000 & \\
\hline & $\mathrm{N}$ & 276 & 276 & 276 & 276 & 276 & 276 & 276 \\
\hline
\end{tabular}

**. Correlation is significant at the 0.01 level (2tailed).

\section{Source: Primary data}

There are significant correlations found between cost estimation and efficiency $(\mathrm{r}=0.885, \mathrm{p}=0.000)$, cost estimation and productivity $(0.934, \mathrm{p}=0.000)$ and between cost estimation and control $(\mathrm{r}=0.897, \mathrm{p}=0.000)$. These correlations were statistically significant given that the $\mathrm{p}$ value was $<0.05$ suggesting that an increase in cost estimation increased the efficiency, productivity and control and the vice versa. For cost budgeting and control $(\mathrm{r}=0.881, \mathrm{p}=0.000)$ and cost budgeting and efficiency $(\mathrm{r}=0.934$, $\mathrm{p}=.000)$ between cost budgeting and productivity $(0.913, \mathrm{p}$ value $=0.000)$ and between cost budgeting and control (986, $\mathrm{p}=0.000$ ). Given that the $\mathrm{p}$ value was $>0.05$ suggesting that an increase in cost budgeting affect efficiency, productivity and control.

There is a significant correlation found between provision of basis for budget control and efficiency $(\mathrm{r}=-0.890, \mathrm{p}=0.000)$. Significant positive correlations were found between Provision of basis for budget control and control $\left(\mathrm{r}=0.935^{*}, \mathrm{p}=0.000\right)$ and with 
control $(r=0.893, p$ value $=0.000)$ given that the $p$ value was $<0.05$ suggesting that an increase in provision of basis for budget control improved efficiency, productivity and control and the vice versa. Positive correlations were found needed material planning and efficiency $(\mathrm{r}=0.891, \mathrm{p}=0.000)$, insignificant correlations also found between needed material planning and productivity $(\mathrm{r}=-$ $0.896, \mathrm{p}=0.000$ ) and a positive correlation was found between needed material planning and improved control $(\mathrm{r}=0.853$, $\mathrm{p}=0.000)$.

\subsection{Effect of Duty planning on the Implementation of Sebeya Watershed Management Project Rubavu District}

This section is concerned with duty planning practices used for the implementation of Sebeya Watershed Management Project Rubavu District. The parameters of duty planning used were capacity of employees, flexibility of employees, collaboration of employees and arrangement of activities.

\section{Correlation between Duty Planning and Implementation Success}

\begin{tabular}{|c|c|c|c|c|c|c|c|c|}
\hline & \multicolumn{3}{|c|}{ Flexibility } & \multirow[b]{2}{*}{$\begin{array}{l}\text { Arrangement } \\
\text { of activities }\end{array}$} & \multirow[b]{2}{*}{$\begin{array}{l}\text { Improved } \\
\text { efficiency }\end{array}$} & \multirow[b]{2}{*}{$\begin{array}{l}\text { Increased } \\
\text { productivity }\end{array}$} & \multirow[b]{2}{*}{$\begin{array}{l}\text { Increasec } \\
\text { control }\end{array}$} \\
\hline & & $\begin{array}{l}\text { Capacity of } \\
\text { Employees }\end{array}$ & $\begin{array}{l}\text { of } \\
\text { Employees }\end{array}$ & $\begin{array}{l}\text { Collaboration } \\
\text { of Employees }\end{array}$ & & & & \\
\hline \multirow[t]{3}{*}{$\begin{array}{l}\text { Capacity } \\
\text { Employees }\end{array}$} & $\begin{array}{l}\text { of Pearson } \\
\text { Correlation }\end{array}$ & 1 & $.882^{* *}$ & $.861^{* *}$ & $.943^{* *}$ & $.953^{* *}$ & $.890^{* *}$ & $.875^{* *}$ \\
\hline & Sig. (2-tailed) & & .000 & .000 & .000 & .000 & .000 & .000 \\
\hline & $\mathrm{N}$ & 276 & 276 & 276 & 276 & 276 & 276 & 276 \\
\hline \multirow[t]{3}{*}{$\begin{array}{l}\text { Flexibility } \\
\text { Employees }\end{array}$} & $\begin{array}{l}\text { of Pearson } \\
\text { Correlation }\end{array}$ & $.882^{* *}$ & 1 & $.916^{* *}$ & $.907^{* *}$ & $.843^{* *}$ & $.985^{* *}$ & $.936^{* * *}$ \\
\hline & Sig. (2-tailed) & .000 & & .000 & .000 & .000 & .000 & .000 \\
\hline & $\mathrm{N}$ & 276 & 276 & 276 & 276 & 276 & 276 & 276 \\
\hline \multirow[t]{3}{*}{$\begin{array}{l}\text { Collaboration } \\
\text { Employees }\end{array}$} & $\begin{array}{l}\text { of Pearson } \\
\text { Correlation }\end{array}$ & $.861^{* * *}$ & $.916^{* * *}$ & 1 & $.883^{* *}$ & $.842^{* * *}$ & $.910^{* * *}$ & $.982^{* * *}$ \\
\hline & Sig. (2-tailed) & .000 & .000 & & .000 & .000 & .000 & .000 \\
\hline & $\mathrm{N}$ & 276 & 276 & 276 & 276 & 276 & 276 & 276 \\
\hline \multirow[t]{3}{*}{$\begin{array}{l}\text { Arrangement } \\
\text { activities }\end{array}$} & $\begin{array}{l}\text { of Pearson } \\
\text { Correlation }\end{array}$ & $.943^{* *}$ & $.907^{* *}$ & $.883^{* *}$ & 1 & $.898^{* *}$ & $.918^{* *}$ & $.897^{* *}$ \\
\hline & Sig. (2-tailed) & .000 & .000 & .000 & & .000 & .000 & .000 \\
\hline & $\mathrm{N}$ & 276 & 276 & 276 & 276 & 276 & 276 & 276 \\
\hline \multirow[t]{3}{*}{ Improved efficiency } & $\begin{array}{l}\text { Pearson } \\
\text { Correlation }\end{array}$ & $.953^{* *}$ & $.843^{* *}$ & $.842^{* *}$ & $.898^{* *}$ & 1 & $.844^{* *}$ & $.851^{* *}$ \\
\hline & Sig. (2-tailed) & .000 & .000 & .000 & .000 & & .000 & .000 \\
\hline & $\mathrm{N}$ & 276 & 276 & 276 & 276 & 276 & 276 & 276 \\
\hline \multirow[t]{3}{*}{$\begin{array}{l}\text { Increased } \\
\text { productivity }\end{array}$} & $\begin{array}{l}\text { Pearson } \\
\text { Correlation }\end{array}$ & $.890^{* *}$ & $.985^{* *}$ & $.910^{* *}$ & $.918^{* *}$ & $.844^{* *}$ & 1 & $.928^{* *}$ \\
\hline & Sig. (2-tailed) & .000 & .000 & .000 & .000 & .000 & & .000 \\
\hline & $\mathrm{N}$ & 276 & 276 & 276 & 276 & 276 & 276 & 276 \\
\hline \multirow[t]{3}{*}{ Increased control } & $\begin{array}{l}\text { Pearson } \\
\text { Correlation }\end{array}$ & $.875^{* *}$ & $.936^{* * *}$ & $.982^{* *}$ & $.897^{* *}$ & $.851^{* *}$ & $.928^{* *}$ & 1 \\
\hline & Sig. (2-tailed) & .000 & .000 & .000 & .000 & .000 & .000 & \\
\hline & $\mathrm{N}$ & 276 & 276 & 276 & 276 & 276 & 276 & 276 \\
\hline
\end{tabular}

**. Correlation is significant at the 0.01 level (2tailed).

\section{Source: Primary data}

In this study, significant positive correlations were found between capacity of employees and increased efficiency $(r=.953$, $\mathrm{p}=.000)$, capacity of employees and increase of productivity $(\mathrm{r}=$ $\left..890^{*}, \mathrm{p}=.000\right)$, and capacity of employees and control $\left(\mathrm{r}=.875^{*}\right.$, $\mathrm{p}=.000$ ). All the correlations were statistically significant given that the $\mathrm{p}$ value was $<0.05$ proposing that an increase in respect of capacity of employees increase efficiency, productivity and control and vice versa. A positive correlation was discovered between flexibility of employees and efficiency ( $r=-843$, $\mathrm{p}=.000)$, flexibility of employees and productivity $\left(\mathrm{r}=.895^{*}\right.$, $\mathrm{p}=.000)$, and with control $\left(\mathrm{r}=.936^{*}, \mathrm{p}=.000\right)$. There were statistically correlated significantly given that the $\mathrm{p}$ value was> 
0.05 suggesting that an increase in flexibility of employees increase efficiency, productivity and control.

Significant positive correlations were found between collaboration of employees and efficiency $(\mathrm{r}=.842, \mathrm{p}=.000)$, collaboration of employees and productivity $(\mathrm{r}=.910, \mathrm{p}=.000)$ and collaboration of employees and control $(\mathrm{r}=-0.982 *, \mathrm{p}=.000)$. All the correlations were statistically significant given that the $\mathrm{p}$ value was $<0.05$ suggesting that an increase in collaboration of employees increase efficiency, productivity, and the vice versa.

Significant positive correlations were found between arrangement of activities and efficiency $(\mathrm{r}=.898, \mathrm{p}=.000)$, arrangement of activities and productivity $(\mathrm{r}=.918, \mathrm{p}=.000)$ and arrangement of activities and control $(\mathrm{r}=-0.897, \mathrm{p}=.000)$. All the correlations were statistically significant given that the $\mathrm{p}$ value was $<0.05$ suggesting that an increase in collaboration of employees increase efficiency, productivity, and the vice versa.

\section{DISCUSSION}

Results on the effect of scope planning were relevants since, Novo et al (2017 utilized desk review and revealed that design management is hardly contained in project planning processes, it stimulates its success via different patterns, such as team work knowledge, manager's skills and methods with both stakeholder and beneficiaries. The study concurs with the findings of Naqvi and Aziz (2011) by assessing the role of stakeholder involvement on project performance. The study revealed a strongly and positive correlation between participation in planning knowledge area is related with setting the responsibilities capacity to employee during the project plan activities, putting the employees in positions according project agenda, and monitoring and evaluation their performances from the plan.

Results on the effect of resource planning did not contract the findings of Mawdsley (2012) who asserts that water management project stimulates efficiency, productivity, and control and demonstrated a strong correlation in all parameters of project planning. However, results from the present study indicate insignificant correlation.

The study results on the effect of duty planning were similars with O’Neil (2016) by reiterating that project planning practices are significantly correlated with the project implementation since the $\mathrm{p}$ value was .000 and an increase of a unit in planning practices increase effective project implementation at .890 in developing countries.

\section{CONCLUSIONS}

From analysis and discussion of information, it is undisputable research objective has been adequately addressed. A strong point discovered in this study was a significant correlation between project planning and implementations success of Sebeya Watershed Management Project. A strong positive correlation occurs also the project scope planning, resource planning and duty planning that permit for Sebeya Watershed Management Project success mainly project short-, medium- and long-term objectives and the assessment contrast relying on solely on water management program success are scaled from 1 to 5 .
Meanwhile, the limitations established in this study are as follow: duty planning are not associated to describe program success owing to no significance of any project success indicators. Through the study objective that intended to copy the concern on the contribution of project planning and implementations success, this study reiterates a positive and significant correlation between project planning and Sebeya Watershed Management project success. Out of this, there are still amelioration essentially toward project success though the following recommendations are proposed.

From the results, there should be cooperation between adjustments in abilities stakeholders and adjustment in Sebeya Watershed Management Project success: Water protection programs should relies on managerial ability for aligning with duty and responsibility planning strategies. The study recommends that the government should assist local communities to establish water committees understand effects of planning via various well managed plan among others. Stakeholders should know that they coordinate programs in suitable ways that are able to stimulate the program success. The study proposed that all project should focus on planning for assessing their short, medium and long -term effect implementation success; this is therefore, owing to planning is helpful in understanding the condition in which they are working and how to address about it.

\section{ACKNOWLEDGMENTS}

I wish to acknowledge Dr. Eugenia Nkechi Irechukwu for her contribution to this work from the beginning up to it's the completion. I also wish to extend my acknowledgement to the Mount Kenya University, Rubavu District authorities for their support and collaborative in term of data collection.

\section{REFERENCES}

[1] Adera, O. B. (2013). Influence of organizational project maturity practices on performance of state corporations. A case of South Nyanza Sugar Company limited. Doctoral dissertation, University of Nairobi. Nairobi, Kenya.

[2] Creswell, J. W. (2013). Qualitative inquiry and research design: Choosing among five approaches. Thousand Oaks, CA: Sage Publications.

[3] Fatima, M., Alyaa, G., \& Abdul, R. (2013). Change Management and its Contribution to the Success of IT Project Implementation. International Journal of Information and Communication Technology Research. 3 (4), 134 -140 .

[4] Harris P. (2010), Project planning and scheduling using Primavera, USA, Easthood Harris Pty Ltd

[5] Heldman, K, (2011), PMP project management professional exam study guide. San Francisco: John wiley \& Son.

[6] Irugal. B, (2018), effects of resource planning on construction project delays in Sri Lanka. International college of business and technology, faculty of engineering and construction. Liverpool John Moores University.

[7] Irugal. B, (2020), effects of resource planning on construction project delays in Sri Lanka. Liverpool John Moores University.

[8] Kayigema, Vincent. \& Rugege, D. (2014). Women's Perceptions of the Girinka (one cow per poor family) program, poverty alleviation and climate resilience in Rwanda. Journal of Empowering Women for Gender Equity, 28(3)53-64.

[9] Margoluis, R. \& Salafsky, N. (2010). Measures of Success. Washington, D.C: Island Press.

[10] Mawdsley (2012). Project management: a managerial approach. John Wiley \& Sons. 
[11] Ministry of Agriculture and Animal Resources [MINAGIRI]. (2012). Livestock Strategic Plan. Kigali: Rwanda. Retrieved from https:// www.minagri.gov.rw\%2F\&usg on 19/April/2021

[12] Moroz S, H., Nemchenko A.S. (2017), upravlinnya zmistom robit [project scope management], Kharkiv: NPhaU. (In Ukrainian)

[13] Mutarutwa, N.C. (2014). Impact of Girinka One Cowper Poor Family Program on Household Income in Gatsibo District, Rwanda. Master's thesis, Kenyatta University, Kenya

[14] Naqvi, I. H., Aziz, S. \& Rehman K-Ur (2011). The impact of Stakeholder communication on project outcome. African Journal of Business Management, 5(14), 5824-5832.

[15] National Institute of Statistics of Rwanda (2015), Rwanda Poverty Profile Report, Integrated Household Living Conditions Survey [EICV] 2013/14

[16] National Institute of statistics of Rwanda. (2011). Living conditions Survey, Kigali: MINECOFIN.

[17] Novo, B., Landis, E. A., \& Haley, M. L. (2017). Leadership and its role in the success of project management. Journal of Leadership, Accountability and Ethics, 14(1),1-6.

[18] Ntanyoma, R.D. (2010). The effect of livestock production on poor and smallholder farmers'income in Rwanda. Pretoria: International Institute of Social Studies.

[19] Obadia. N, Patrick. M, (2018), effect of resources management on project success implementation. A case of strengthening livelihoods in rural Rwanda project. JomoKenyatta University of Agriculture and technology, department of ETLM. International journal of research in management, economics and commerce.
[20] Ofori, D. (2013). Project Management Practices and Critical Success Factors-A Developing Country Perspective. International Journal of Business and Management, 8 (21), 14 - 31.

[21] Rubavu, (2020). Watershed Management for Sebeya Catchment. Annual Report. Rubavu District, Rwanda.

[22] Ruberangeyo, A. Ayabare M \& Laminne. B. (2011). Rwanda Social protection: an ongoing process, in UNDP Sharing innovative experiences, successful social protection floor experiences, global south-south Development Academy, ISSN: 1728-4171, (18) 333-360

[23] Rwanda Agricultural Board. (2013). The One Cow per Poor Family Program (Girinka) in Rwanda, Kigali. Retrieved from https:// rab.gov.rw/index.php? id

[24] Yana. D, (2018), project scope management process. National University of Pharmacy, Ukraine, Baltic journal of economic studies, Vol. 4, No1.

[25] Yang, L. R., Huang, C. F., \& Wu, K. S. (2011). The association among project manager's leadership style, teamwork and project success. International journal of project management, 29(3), 258-267.

\section{AUTHORS}

First Author - Mathias Karasira, School of Business and Economics, Mount Kenya University, Kigali, Rwanda Second Author - Dr. Eugenia Nkechi Irechukwu, School of Business and Economics, Mount Kenya University, Kigali, Rwanda 